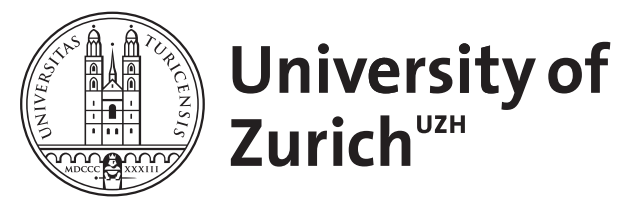

\title{
Trade-offs are not exogenous
}

Deflorin, Patricia ; Scherrer-Rathje, Maike

\begin{abstract}
Trade-offs between competitive priorities are often seen as exogenous - managers accept them as a given downside while simultaneously addressing multiple competitive priorities. However, some companies seem to face fewer trade-offs than others. The question is how companies reduce their tradeoffs to successfully compete on multiple competitive priorities simultaneously. We address this question by theorising that bundles of action programmes are needed to reduce trade-offs between competitive priorities. We examine four Swiss manufacturing plants and show how the selection of action programmes influences the simultaneous competition on multiple competitive priorities. We show that successful competition on multiple competitive priorities does not happen by accident but is achieved by aligning competitive priorities, action programmes, infrastructural/structural changes and contextual factors.
\end{abstract}

DOI: https://doi.org/10.1080/00207543.2013.784406

Posted at the Zurich Open Repository and Archive, University of Zurich ZORA URL: https://doi.org/10.5167/uzh-88030

Journal Article

Accepted Version

Originally published at:

Deflorin, Patricia; Scherrer-Rathje, Maike (2013). Trade-offs are not exogenous. International Journal of Production Research, 51(15):4644-4666.

DOI: https://doi.org/10.1080/00207543.2013.784406 


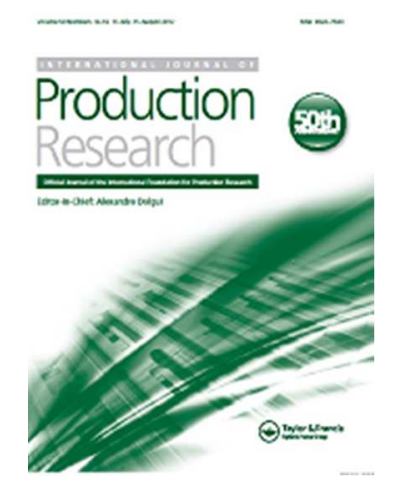

\section{Tradeoffs are not Exogenous}

\begin{tabular}{|r|l|}
\hline Journal: & International Journal of Production Research \\
\hline Manuscript ID: & TPRS-2012-IJPR-0145.R2 \\
\hline Manuscript Type: & Original Manuscript \\
\hline Complete List of Authors: & $\begin{array}{l}\text { Deflorin, Patricia; University of Zurich, Department of Business } \\
\text { Administration } \\
\text { Scherrer-Rathje, Maike; University of St.Gallen, Institute of Technology } \\
\text { Management }\end{array}$ \\
\hline Keywords: & $\begin{array}{l}\text { CONTINUOUS IMPROVEMENT, OPERATIONS STRATEGY, CASE BASED } \\
\text { REASONING }\end{array}$ \\
\hline Keywords (user): & Tradeoffs \\
\hline &
\end{tabular}

SCHOLARONE ${ }^{m}$

Manuscripts 


\section{Tradeoffs are not Exogenous}

P. Deflorin a* and M. Scherrer-Rathje b

a Department of Business Administration, University of Zurich, Zurich, Switzerland

b Institute of Technology Management, University of St. Gallen, St. Gallen, Switzerland

Word count: 8825

*Corresponding author's email: patricia.deflorin@business.uzh.ch

http://mc.manuscriptcentral.com/tprs Email: ijpr@tandf.co.uk 


\section{Tradeoffs are not Exogenous}

Tradeoffs between competitive priorities are often seen as exogenous - managers accept them as a given downside while simultaneously addressing multiple competitive priorities. However, some companies seem to face fewer tradeoffs than others. The question is how companies reduce their trade-offs to successfully compete on multiple competitive priorities simultaneously. We address this question by theorising that bundles of action programmes are needed to reduce tradeoffs between competitive priorities. We examine four Swiss manufacturing plants and show how the selection of action programmes influences the simultaneous competition on multiple competitive priorities. We show that successful competition on multiple competitive priorities does not happen by accident but is achieved by aligning competitive priorities, action programmes, infrastructural/structural changes and contextual factors.

Keywords: competitive priorities, tradeoffs, practises, case studies 


\section{Introduction}

Tradeoffs between competitive priorities are often seen as exogenous, that is, managers accept them as a given downside while simultaneously addressing multiple competitive priorities. However, some companies seem to face fewer tradeoffs than others. Although widely studied, results are diverging as to whether simultaneous competition on multiple competitive priorities leads to tradeoffs (Boyer and Lewis 2002, Corbett and Van Wassenhove 1993, Schroeder et al. 2011). To fulfil competitive priorities, a firm must often change its processes through the implementation of action programmes. Unfortunately, there is no single action programme that simultaneously influences multiple competitive priorities (Ketokivi and Schroeder 2004b). Depending on the contextual factors, different action programmes may influence different sets of competitive priorities differently. However, there is a lack of research focusing on the interdependencies of these dimensions (Christiansen et al. 2003, Schroeder et al. 2011).

The purpose of our paper is to show what managerial actions are needed to fulfil multiple competitive priorities simultaneously. In doing so, we study the relationships between competitive priorities, managerial actions, contextual factors and performance. We add to the existing body of literature on manufacturing strategy content by linking competitive priorities to the actions required and demonstrate how tradeoffs are reduced. We also show how contextual factors influence the actions needed to manage multiple competitive priorities. To grasp the interdependencies between action programmes, competitive priorities and contextual factors we derive comprehensive causal loop diagrams (CLD) (Sterman 2000).

Our research focuses on contextual factors, strategic goals, the means to realise these goals and how the orchestration of these dimensions can influence performance. 
Whereas other authors have focused on the strategy formulation process and the effect on performance (e.g. Brown et al. 2010), we focus on the implementation of manufacturing strategy content. To describe strategic goals, the term competitive priorities is widely applied in operations management research. The lowest common denominators are represented by three competitive priorities: cost, quality and dependability (Dangayach and Deshmukh 2001). Other widely applied goals include flexibility (Anand and Ward 2004, Groessler 2007) and innovation (He and Wong 2004, Miltenburg 2009). We consider these five competitive priorities in our work. These competitive priorities are similar to Hill's (2000) concept of order-winning (precondition of superior success) and order-qualifying criteria (basis to be competitive). Although the order winner/qualifier distinction has considerable intuitive appeal, Spring and Boaden (1997) argue that if the tradeoff principle is to be adopted, then the concept of competitive priorities is more useful than order winners.

Even though the most studied content of manufacturing strategy is structural and infrastructural decisions (Hill 2000), analysing action programmes as part of manufacturing strategy content has received growing interest among researchers (Laugen et al. 2005, Christiansen et al. 2003, Narasimhan et al. 2005). Action programmes (e.g., just-in-time) are activities that help to achieve a desired end and provide structure regarding how activities must be conducted within a company to achieve a defined goal. Kim and Arnold (1996) state that competitive priorities must be linked explicitly to action programmes such that manufacturing executives can have an array of alternatives from which to choose in achieving their firm's competitive priorities. This perspective highlights the process perspective (Wheelwright and Hayes 1985) and the notion that the implementation of processes and practices builds up capabilities which are needed to compete successfully (Hayes and Pisano 1996, Clark 
1996). The purpose of an operations strategy is to assemble and align the resources that will enable manufacturing to implement its company's goal (Hayes et al. 2005). Thus, we follow this process-oriented approach with regard to manufacturing strategy content. The implementation of practices is highly interlinked with structural and infrastructural changes. For example, Mills et al. (1995) argue that the implementation of cells involves decisions and actions to invest in more equipment and to update manufacturing control system if full benefits are to be obtained. Therefore, the process perspective of manufacturing strategy content is complemented with structural and infrastructural initiatives. Mills et al. (1995) provide an overview of the decision categories as used by different authors.

As Schroeder et al. (2011) highlight, the improvement of competitive priorities may be influenced by different factors. Successful implementations of action programmes often depend on contextual factors such as industry, product characteristics or automation level. Therefore, not all organisations can or should implement the same practises to achieve a similar goal.

Implementing competitive priorities through action programmes influences the firm's performance (Ketokivi and Schroeder 2004a). If the negative effects among the chosen competitive priorities are not solved through suitable actions, then these effects will negatively influence market performance. Selecting the appropriate measures of performance is a challenging task. Although some researchers favour financial performance indicators (Chen and Paulraj 2004), others have criticised the limitations of relying solely on financial measures of performance (Flynn et al. 2010), especially as they do not reflect the multidimensionality of the manufacturing action programmes (Ketokivi and Schroeder 2004a). Similar to strategic priorities, performance is a multidimensional construct and has to cover the same dimensions as the competitive 
priorities (quality, dependability, flexibility and innovation). Bozarth and Edwards (1997) note the difficulty of comparing objective measures across units with different technologies and product lines. In such situations, Ketokivi and Schroeder (2004a) consider perceptual measures to be a valuable alternative. Evidence for the validity of perceptual measures of performance is provided by Ward et al. (1994), Ward et al. (1998) and Vickery et al. (1997).

Figure 1 depicts the relevant dimensions of manufacturing strategy content for this research: the multidimensionality of competitive priorities and performance dimensions and the actions to turn the strategic goals (competitive priorities) into performance dimensions. The underlying research questions are also related to the figure.

\section{- Take in Figure 1 -}

\section{Challenges and Research Focus}

\subsection{Companies struggle with multiple competitive priorities}

Skinner $(1969 ; 1974)$ argues that companies must focus on one priority at a time, as the competitive priorities require different organisational structures and infrastructures. Given resource constraints, companies cannot afford to improve everything at the same time. According to Skinner, improvements in one goal lead to a decline in other factors (Skinner 1969, Skinner 1974). Subsequent tradeoff studies examine the need for plants to prioritise their strategic objectives and corresponding resources (Da Silveira 2005, Da Silveira and Slack 2001, Mapes et al. 1997, Schroeder and Pesch 1994). In contrast, advocates of cumulative competitive priorities claim that global competition leads to increased pressure to compete on multiple priorities (Boyer and Lewis 2002). Different studies show that competitive priorities reinforce each other, which allows the 
simultaneous competition on multiple competitive priorities (Christiansen et al. 2003, Corbett and Van Wassenhove 1993, Ferdows and De Meyer 1990, Frohlich and Dixon 2001, Kathuria 2000, Noble 1997, Ritzman and Safizadeh 1999, Roth and Morrison 1992, Ferdows and Thurnheer 2011). Ferdows et al. (1986) even suggest a pre-specified order for building manufacturing capabilities. Nonetheless, how companies simultaneously compete on multiple competitive priorities and which combinations lead to tradeoffs remains unclear (Schroeder et al. 2011). We contribute to this literature by showing how manufacturing plants simultaneously implement multiple competitive priorities, and if and how these strategies lead to tradeoffs.

RQ1: Which combinations of competitive priorities lead to tradeoffs and why?

\subsection{Bundles of practises / action programmes}

According to Christiansen et al. (2003) and Frohlich and Dixon (2001), competing on multiple priorities requires implementing a bundle of practises. A bundle of practises is necessary, as no single practise appears to universally demonstrate competitive value in all performance dimensions (Ketokivi and Schroeder 2004a). Although researchers recognise the value of investigating interrelated entities at the same time, studies are scarce. Three exceptions are the works of Shah and Ward $(2003,2007)$ and Cua et al. (2001), all of whom analyse a bundle of manufacturing practises and its impact on performance. Although the studies show that the bundles exert a joint effect on performance, we still do not know how these bundles interact and how the diversity of practise bundles influences the multidimensional performance measures. Shah and Ward (2007) originally formed the term "bundle of practises". They describe lean production as a bundle consisting of JIT, TPM, statistical process control (SPC) and supplier management. 
Directly analysing a bundle of practises (e.g., lean) is difficult. Therefore, we examine the underlying practises (e.g., JIT) implemented by the companies. We add to the existing literature by analysing the practises implemented by four manufacturing companies and highlighting these practises' interactions and their joint effects on performance.

RQ2: Do action programmes influence the simultaneous implementation of multiple competitive priorities?

\subsection{One-dimensional focus}

Schroeder et al. (2011) analysed whether companies follow a defined order when building the strength to compete simultaneously on multiple competitive priorities and conclude that there is not a universal sequence but that other influencing factors exist. However, most research on manufacturing strategy content is a-contextual and often fails to consider influencing factors. Even the comprehensive literature review of Dangayach and Deshmukh (2001) does not include contextual factors. For example, Flynn and Flynn (2004) and Corbett and Claridge (2002) found some differences in the patterns of cumulative capabilities between countries and industries. We argue that company specific factors influence tradeoffs and, therefore, aim to explore why similar goals and actions do not lead to the same results. For example, changes in the production process in highly automated plants require different actions than in plants with a job-shop philosophy (Deflorin and Scherrer-Rathje 2011).

RQ3: Which contextual factors influence the relationships between competitive priorities, managerial actions and performance? 


\subsection{Interrelation of contextual factors, competitive priorities, managerial} actions and multidimensional performance

According to the theory of "fit" (Venkatraman 1989), an independent analysis of competitive priorities, managerial actions, performance and contextual factors leads to a suboptimal result. In addition to many articles focusing on one or two of the named dimensions, we found six papers that address at least three of the four dimensions. Within Christiansen's et al. (2003) and Kim and Arnold's (1996) analyses, the missing dimension is the one containing contextual factors. Cua et al. (2001) and Laugen et al. (2005) neglect the influence of the strategic choice, whereas Dean and Snell (1996) and Kim and Arnold (1996) do not consider multidimensional performance. Ketokivi and Schroeder's (2004a) work includes all four dimensions (i.e., contextual factors, competitive priorities, action programmes, performance), but because of the statistically derived influences, the work fails to provide an in-depth discussion and understanding of the relationships. For instance, their work does not clearly explicate how a set of competitive priorities and a special bundle of practises are connected. Furthermore, the authors do not recess the relationships among the competitive priorities, and, therefore, the discussion of tradeoffs is missing.

RQ4: How does a company orchestrate contextual factors, competitive priorities and managerial actions to avoid tradeoffs that negatively influence the multidimensional performance indicators?

\section{Methodology}

\subsection{Research setting}

The goal of our analysis is to gain new insights into how multiple competitive priorities can be addressed by firms. We chose a qualitative, case-based approach for two main 
reasons. The study investigates why manufacturing tradeoffs exist and how companies address them (Yin 1994). To date, research has been mainly driven by the "what" approach, which demonstrates that companies compete on multiple competitive priorities at the same time. To achieve our research goal, we followed the research strategy of relationship building (Handfield and Melynk 1998). In this strategy, questions are pursued asking what patterns link variables, if an order in their relationships can be identified or why the relationships exist in the first place. Results can be achieved through focused or best-in-class case studies (Stuart et al. 2002).

The traditional way of sampling cases is to identify a suitable population and then to randomly select cases out of this population (Voss et al. 2002). Overall, we identified 280 possible companies that promised suitable for our study. As we aimed at studying best-in-class cases, we decided to conduct a questionnaire based survey for case selection. Following the recommendations of Dilman (1978) and Oppenheim (1992) for ensuring validity of results, questions were designed based on a thorough literature analysis. The questionnaire was pretested and then sent to CEOs or manufacturing managers of Swiss manufacturing companies from industries with ISIC codes 28 to 35 . Overall, 64 questionnaires were returned which equals a response rate of $23 \%$.

After a cluster analysis, we selected companies as best-in-class cases claiming to simultaneously compete on multiple competitive priorities and, at the same time, achieve a better performance than their competitors. To ensure their appropriateness as best-in-class, we conducted phone calls to verify the given answers. We ended up with a sample of four cases which we studied in greater detail. The number of cases is adequate based on recommendations in literature (Eisenhardt 1989, Stuart et al. 2002). 
The companies were well-known Swiss manufacturers with a long standing tradition in their markets.

The unit of analysis is a single plant. Part of the research involved selecting a plant that is clearly focused on a single product or product line following the same strategic goals, as analysing a plant with a diverse product portfolio would not lead to clear results. For example, a portfolio manager could independently manage products with a low cost focus and products with a strategic goal of high quality at the same time. However, achieving a high performance for multiple competitive priorities in a focused product portfolio requires managers to simultaneously direct the strategic goals.

\subsection{Data collection}

Starting point of the in depth case studies was the questionnaire. Based on these information, we (1) led an interview with the CEO; (2) executed an interview with the manufacturing manager; (3) undertook a joint interview with the CEO and manufacturing manager; (4) observed shop floor activities; (5) analysed corporate documents; and (6) conducted follow-up interviews to verify the researcher's interpretations.

All interviews and site visits were conducted by two operations management researchers in 2007. Our main goal was to analyse the changes achieved through the implementation of the action programmes. Each interview was semi-structured, recorded and scheduled to last three to four hours. The individual interviews with the CEO and manufacturing manager were based on the same questionnaire (see Appendix). During the third interview, both managers discussed their answers and, in the case of differences, eventually reached consensus through argumentation. We used multiple informants because we did not want to retrieve the retrospective data from just one informant (Eisenhardt and Zbarac 1992). Furthermore, the joint interview of the 
CEO and manufacturing manager led to additional information as different interpretations were discussed, and a single solution was achieved through joint reasoning. To substantiate the information submitted in the questionnaire, top management provided additional documentation, such as the company's documents and presentations. Finally, we conducted the follow-up interviews to test our interpretation of the data provided by the management.

\subsection{Data analysis}

We began the data analysis by utilising traditional methods of inductive fieldwork (e.g. Miles and Huberman 1994). One of the researchers wrote detailed case studies based on the recorded transcripts and archival data. The other researcher reviewed the cases. If a disagreement occurred, the topic was brought back to the company's representatives for clarification. This procedure allowed us to check for inter-rater reliability (Voss et al. 2002). To perform a cross-case analysis, we derived various tables and diagrams. To derive the relationships between the dimensions, we used system dynamics, respectively causal loop diagrams (CLD) (Sterman 2000). CLD is a method to identify cause-effect relations. It is especially useful if the research focus is of vaguely understood interactions (Davis et al. 2007). It can help to grasp the dynamic relations within systems and how they affect each other, such as important interrelations (Repenning \& Sterman, 2002; Senge, 1990; Sterman, 2000) that exist between competitive priorities, action programs and other initiatives to address the competitive priorities.

In the CLD, all relevant competitive priorities and all practices and initiatives stated to achieve the respective competitive priorities are written down. Then, factors affecting other factors are connected by an arrow. The direction of change is symbolized with a plus $(+)$ or a minus $(-)$. A minus indicates a change of direction (e.g. if the influencing factor increases, the influenced factor decreases) whereas a plus 
describes the same direction (e.g. if the influencing factor increases, the influenced factor increases as well).

The analysis contained an excerpt of the action programmes implemented by the four companies studied. The programmes were chosen according to the following criteria:

(1) The strategic importance of the programme must be determined by its influence on more than one competitive priority.

(2) The implementation must have started less than 5 years ago. The influence of the programme on competitive priorities is especially vital during the implementation process, as the management is aware of the changes during this period. The influence of older programmes tends to become blurred such that the effects cannot be separately analysed.

(3) The results of the programme must be manageable and able to be influenced by the management (e.g., the result of the programme "supplier management" is partly under the responsibility of the supplier's behaviour).

Finally, we performed a cross-case analysis. The key point was the comparison of the causal loop diagrams and the tables. Based on the comparisons of the differences and the similarities between the dimension of the manufacturing strategy framework and the framework's relationships, we derived the implications for our theory.

\section{Company Description: Key Characteristics and Competitive Priorities}

-Take in Table 1-

Cable Ltd. is a machine manufacturer with its headquarters in Switzerland. The group achieves sales of 200 Mio $€$ and earnings before interest and taxes (EBIT) of 24 Mio $€$. Our unit of analysis is the Swiss plant. The plant's product portfolio is different 
from the others within the network in that the other plants focus on more customised machinery or on different customer industries. Thus, the company follows a strategy of focused product portfolios within their plants. Cable Ltd. is a market leader with a market share of $40 \%$. Its strong market position is mirrored in Cable Ltd.'s perceptual performance measures (see Table 2). Row A indicates the degree of importance to which this priority must be fulfilled by the companies to be successful. Each company still has to decide if an important factor is included in the manufacturing strategy. Row $\mathrm{B}$ shows the factors that the company aims to implement. Row $\mathrm{C}$ indicates if the members of the company believe that they have a higher level of performance than their relevant competitors.

The "price" and "frequency of new product introduction" were judged to be of medium importance. The priority "price" is defined from a customer perspective. Cable Ltd. indicated that they do not compete for a low price, but low manufacturing costs are an important goal. The priority, "new product introduction", is mid-ranked because customers who are familiar with the reliability of the machines are not as interested in buying new machines as long as the older model performs with high efficiency.

-Take in Table 2-

Pipe Systems is a manufacturer of plastic equipment. Each plant is focused on a specified product spectrum. Pipe Systems is market leader and generates 570 Mio $€$ sales and an EBIT of 130 Mio $€$. It shares the bigger part of the market volume with another competitor whereas a few niche players account for the rest. The unit of analysis is the Swiss production plant.

With the exception of price/cost, Pipe Systems considers itself to perform better on eight competitive priorities. From a strategic perspective, two priorities ("fast delivery" and "volume flexibility") are of medium importance, as the end-product 
inventory is owned and stored by the sales representatives. Price differentiation is not a strategic goal. However, low internal costs are important.

Printer Board Ltd. is a manufacturer of electrical machinery and apparatuses. It generates sales of 183 Mio $€$. The company ranks $4^{\text {th }}$ in the market. The management judges that it achieves a higher performance level on four out of nine competitive priorities. Although the factor "innovative products" is of medium importance for winning customer orders, the company does not include it as a strategic goal, as customers prefer to have reliable and tested products.

Tool Ltd. has its headquarters in Switzerland and produces fabricated metal products. It generates 60 Mio $€$ sales and ranks $3^{\text {rd }}$ in its market. The Swiss plant has a standardised, though large, product portfolio consisting of 15,000 different tools. The competitive priorities within the product portfolio are similar. To cope with the large product portfolio and its aim to become an innovative tool producer, Tool Ltd. has developed a close and intense relationship with its suppliers. One of the goals of Tool Ltd. is to invest in the automation level of the machines, which has been done heavily over the last three years. Nevertheless, the processes in between are still mainly manual. Seven competitive priorities were given high importance, and two are of medium importance.

\section{Tradeoffs and initiatives}

The case analysis of the four Swiss plants has revealed that the simultaneous competition on multiple competitive priorities leads to three tradeoffs. The following section highlights the encountered tradeoffs and shows which practises and initiatives the companies have implemented to reduce the negative effects. 


\subsection{The effects of improving "volume flexibility"}

The improvement of volume flexibility is often accompanied with a negative influence on other competitive priorities. In our sample, all four companies reveal tradeoffs between "volume flexibility" and "low costs", "product design and quality", “conformance quality", "dependable delivery" and "fast delivery".

In order to react flexibly to volume changes, companies tend to have spare capacity (Gerwin 1993). However, in order to be able to achieve low cost, the analysed companies strive to operate at full capacity. This leads to the volume flexibility and low cost tradeoff. In addition, the companies report that a high degree of volume flexibility has a negative influence on process stability. Process stability, however, is needed to achieve the following competitive priorities: "product design and quality", "conformance quality", "dependable delivery", "fast delivery" and "low cost". More specific, unstable processes increase throughput time. A higher throughput time negatively influences the priority for fast delivery and leads to higher costs. In addition, process stability is also a prerequisite for process transparency. If the higher volume flexibility causes lower process stability, process transparency is negatively influenced, which, in turn, negatively influences the competitive priorities "product design and quality", "conformance quality" and "dependable delivery".

\subsubsection{Practises to reduce the "volume flexibility" tradeoff}

In order to reduce the above mentioned tradeoffs, the analysed companies implement action programs and other initiatives. The tradeoffs resulting from the priority "volume flexibility" have triggered the implementation of a specific practise: just-in-time (JIT). Each of the studied companies implemented the JIT initiative to shorten the throughput time, to have transparent and low cost processes and to maintain high flexibility. For example, Cable Ltd. started to implement JIT five years ago. The production manager 
of Cable Ltd. explained, "We defined strategic goals of production, assembly and logistics. We knew that production and assembly needs to have short throughput time and direct processes in order to achieve low production costs. In addition, we need to be highly flexible. It was clear that we need to implement JIT', The initiative covered the pull-system, reduction in set-up time, equipment layout and adherence to a daily schedule. Cable Ltd.'s management notes that one of the key changes of the JIT implementation was higher process transparency. This transparency was achieved by conducting various training sessions during the implementation, outlining clearly defined tasks, enforcing adherence to task specifications and improving the processoriented thinking of the employees. The higher process transparency resulted in more stable processes and, hence, lowered the negative influence of "volume flexibility". The causal loop diagram visualizes the above described causalities and how the achieved changes allowed Cable Ltd. to reduce tradeoffs and to successfully compete on multiple competitive priorities simultaneously (see Figure 2; competitive priorities are highlighted in italic typing).

- Take in Figure 2-

While implementing JIT, Pipe Systems' employees were obliged to attend training programmes that helped them to understand the new philosophy and strengthen their process-oriented thinking. The implementation led to improved processes and to a reduction of waste. Because of the high automation level, improving change over time was central. In sum, the key changes achieved were the developments in the processoriented thinking and a higher adherence to task specifications. This led to a higher transparency, more stable processes and to a reduction of the volume flexibility tradeoff. The causalities are presented in Figure 3. 
- Take in Figure 3-

Printer Board Ltd. implemented JIT, which consists of a pull-system, reduction in set-up time, equipment layout and adherence to a daily schedule. The implementation was initiated three years ago. The goal was to be able to efficiently manage the broad product portfolio and to combine dependable delivery with a fast process without incurring high inventory costs. Similar to the causalities seen at Pipe Systems and Cable Inc., the production manager summarises, "The implementation of JIT was a key driver for strengthening process-oriented thinking. The ability of the employees to understand the nature of the processes is key for improvement suggestions".

- Take in Figure 4-

Tool Ltd.'s CEO explained that during the implementation of JIT, the shop floor was separated into three main processes: intermediate goods, almost finished goods and finished goods. Each of the steps was managed according to JIT. Its implementation led to an integrated database. These two main changes positively influenced transparency as it was much easier to understand the interactions of the process. The knowledge of the interactions helped the employees understand the importance of adhering to the process specifications. Consequently, process stability was improved.

- Take in Figure 5-

\subsubsection{Initiatives to reduce the "volume flexibility" tradeoff}

Cable Ltd.'s production manager stressed that “JIT was not enough. We were still fighting to produce at full capacity and, at the same time, to be able to react flexibly to changing customer orders. Hence, we started to buy additional capacity from the market. If needed, we employed temporary personnel. With them we can increase our working hours up to $150 \%$. Temporally employing external personnel is only possible because of the newly gained process transparency. Internal employees can easily switch 
between different tasks and temporal employees can take over the easier tasks".

In addition, Cable Ltd. installed another initiative to reduce the tradeoffs related to "volume flexibility" by distinguishing among three different production lines. The production lines are structured according to batch size and throughput time. The "normal" production line covers products with a throughput time of more than five days, the flex-shop with less than five days and the express-shop with less than 48 hours. This distinction allows the company to react flexibly without negatively influencing other production lines. Furthermore, the management stated that the implementation of three different production lines has resulted in lower overall costs because each line runs efficiently.

Printer Board Ltd. and Tool Ltd. responded to the flexibility tradeoff by developing a stronger relationship within the internal manufacturing network. Printer Board Ltd.'s sister plants have similar capabilities and technologies. To be able to react to changing volumes, the management can transfer the order to one of the sister plants. Tool Ltd. transferred mature products to a low-cost plant and achieved an overall cost reduction of $30 \%$. This step helped to maintain the utilisation capacity at a level where changes in volumes and the testing and introduction of new products were possible. Doing so reduced the negative effect of "volume flexibility".

Pipe Systems reduced the tradeoffs resulting from the factor "volume flexibility" by improving the automation level of the processes. The management stresses that, because of the high automation level of each process step, changes in the first process step did not lead to an increase in process variance in the subsequent process step. "Flexible changes are only possible if there is no decision leeway of the machinehandling employees. We therefore aim to have highly automated machines and 
processes and high standardisation. Hence, process variances are minimised even if we flexibly react to changing customer volumes".

The action programmes and initiatives which allowed the companies to reduce the volume flexibility tradeoff are summarized in Figure 6.

\subsection{The effects of improving "frequency of new product introduction"}

Additional tradeoffs were identified from the factor "frequency of new product introduction". The processes needed to produce an existing product portfolio are often optimised to a point where process variances are reduced to a minimal level. Low variances are the foundation of continuous high quality and dependability levels. The introduction of new products is bound to produce variances because the processes must be adapted to the new circumstances and be optimised to reduce process variance. The longer throughput time of the new processes is the factor that influences costs. The impact of a high frequency of new product introduction is one of the key challenges for Tool Ltd's. CEO. 'Every year, we offer up to 500 new products. We need to have stable and transparent processes. If every new product introduction results in high process variances, we not only endanger costs, but also quality, dependability and speed. Hence, one of the key challenges is to reduce the negative effects of new product introductions".

Each of the analysed companies faced the challenge that a higher frequency of new product introduction endangers process stability. Unstable processes negatively influence "low costs", "product design and quality", "conformance quality", “dependable delivery" and "fast delivery".

\subsubsection{Practises to reduce the "frequency of new product introduction" tradeoff}

Two companies, Printer Board Ltd. and Tool Ltd., highlight the influence of the JIT 
practise. The companies concluded that JIT allowed the companies to implement new products more easily because of its transparent processes, which resulted in the potential to more frequently introduce new products. Once again, the implementation of JIT was chosen to improve process transparency and stability and therefore helped not only to reduce the "volume flexibility" but also the "frequency of new product introduction" tradeoff.

The analysis of Cable Inc. and Printer Board Ltd. showed the influence of the practise "continuous improvement" (CI). After a new product introduction, the processes must be optimised to reach the same efficiency level as before. The employees' efforts to continuously improve the processes helped, and the prior efficiency level was achieved much faster than without the continuous improvement practise. Printer Boards' CEO stresses that "This programme helped to bring new processes to the same level of quality and speed as the old ones. However, we still cannot avoid the tradeoffs or immediately reduce them. Continuous improvement can help mitigate the encountered effects as soon as possible".

Another practise that supported the reduction of the negative effects of improving the frequency of new product introduction is the "integration of product development and production". Pipe Systems, Printer Board Ltd. and Tool Ltd. implemented the practise and found that it promoted the sharing of knowledge between two units, supported the manufacturability of the product and reduced the iterations between development and production. Furthermore, the implementation strengthened the production- and process-know-how of the employees, both of which are key criteria during the development and improvement of products. The project also strengthened the employees' knowledge concerning the deployment of suitable production procedures, which was a driver for the reduction of costs and the improvement of conformance 
quality. At Tool Ltd., the practise covered the definition of four technical coaches. The four employees were responsible for improving the new product introduction process and for improving the existing production processes. Instead of a CI programme, the company decided to give the responsibility of process improvements to the four technical coaches. The resulting changes encompassed the automation level, the reduction of change over time and the general transparency improvements.

Cable Ltd. installed a practise called "Project Management” (PM). Traditionally, all efforts to implement a new project (product or practise) had to be performed in addition to the normal workload. After the implementation of PM, the firm's responsible employees were allowed to exclusively focus on an efficient and effective project implementation process. Furthermore, a small unit was tasked with supporting the implementation of new projects with tools, materials, data and experience. Because of the shorter new product implementation time, the frequency of new product introduction increased, and the company was also able to widen its product range. Furthermore, with each completed project, the project management's experience increased. This additional experience led to improvements in choosing the right methods for an effective product implementation process. This learning effect contributed to lowering the effect of new product introduction on process stability and, as a result, lowered the negative performance effects.

\subsubsection{Initiatives to reduce the "frequency of new product introduction" tradeoff}

In addition to the practises implemented to reduce the tradeoffs resulting from the "frequency of new product introduction", the analysis of Pipe Systems and Tool Ltd. revealed two additional initiatives. Pipe Systems reduced the tradeoffs through process automation. The less each subsequent or parallel process was influenced by a new product introduction, the lower were the resulting tradeoffs from a new product 
introduction. A high automation level, therefore, reduced the effects of the "frequency of new product introduction" and "volume flexibility".

The investment in the eastern European plant allowed Tool Ltd. to have a higher frequency of new product introduction without increasing the total costs because of the spare capacity at the Swiss plant. Thus, the tradeoff between the new product introduction and the costs was reduced. The spare capacity at the Swiss plant allowed for the introduction of new products with a lower negative effect on the priorities "product design and quality", "conformance quality", "dependable delivery" and "fast delivery" in comparison to the plant when at full capacity.

In addition to the reduction from the implementation of "CI" and the “integration of product development and production", Printer Board Ltd. accepted the tradeoffs resulting from "new product introduction". The production manager reasoned that "The tradeoffs could be reduced by implementing a production line dedicated to prototypes. However, we think that the tradeoffs are worth accepting because of the learning achieved through the direct ramp-up".

\subsection{The effects of improving "fast delivery"}

Cable Ltd.'s project manager highlighted another tradeoff. “The customers' requests for express deliveries produced in between the scheduled production volume resulted in process variations. As we wanted to be able to solve the customers' needs, we needed to secure process stability. It was clear that process transparency is key. JIT, CI and PM all helped to reduce this challenge". Whereas the "in between requests for express deliveries" was only mentioned by Cable Ltd., all managers highlighted the customers pressure for fast deliveries. Cable Ltd., Printer Board Ltd. and Tool Ltd. faced tradeoffs resulting from the aim to fulfil this customer need. 
Printer Board Ltd. has made-to-order products with no storage, thus the pressure to deliver faster had to be solved directly through a lower throughput time. Printer Board Ltd.'s CEO reported that "In some circumstances we had to decline customer orders, as we would have to put too much pressure on the processes and employees to fulfil these requests. From experience, this resulted too often in process variances which we later had to cope with".

Tool Ltd.'s analysis reported a similar issue concerning the customers need for faster deliveries. However, the company's investments in end product storage shifted the pressure away from the processes. Hence, the only remaining tradeoff is "fast delivery" and "low cost" as the end product storage is costly.

\subsubsection{Practises to reduce the "fast delivery" tradeoff}

The description resulting from the "fast delivery" tradeoff shows that the main issue concerns the influence on process variances and instability. The lower the process transparency, the higher the negative effect on costs, quality and dependability. Hence, the supporting practises focus on strengthening process transparency.

Cable Ltd. responded to the "fast delivery" tradeoff with the implementation of three practises: JIT, CI and PM. The implementation of JIT was supported through training sessions, as previously mentioned. Likewise, the practises of CI advanced the process transparency and was a central element in strengthening the employees' knowledge about processes. Furthermore, many of the improvement suggestions resulted in improved processes and a higher transparency. Finally, the third practise influencing process transparency was PM. Each new product introduction was accompanied with clear process specifications, employee training and influenced process transparency. In sum, because of the newly gained process transparency, 
process variances were detected earlier and respective measures lowered the negative effects.

Similar to Cable Ltd., Printer Board Ltd. highlighted the practises of JIT (higher process stability), continuous improvement (improvement of processes), and the integration between product development and production (efficient and effective project management) to reduce the "fast delivery" tradeoff.

\subsubsection{Initiatives to reduce the "fast delivery" tradeoff}

Cable Ltd. responded to the "fast delivery" tradeoff by implementing two additional lines: the flex- and express-shop. This investment allowed the company to accept customer express orders without influencing the process stability of high volume products.

Table 3 summarizes the lessons learned from each case and exemplifies which initiatives supported the reduction of tradeoffs. Hence, tradeoffs are not exogenous but an orchestrated implementation of action programs and initiatives supports the reduction of tradeoffs.

\section{-Take in Table 3-}

\section{Discussion}

The following paragraph compares the presented data and aims to address the research questions of this paper.

\subsection{RQ1: Which combinations of competitive priorities lead to tradeoffs and why?}

Each of the analysed companies strives to fulfil multiple competitive priorities, which lead to tradeoffs. The case studies show that three priorities, namely "volume 
flexibility", "frequency of new product introduction" and "fast delivery", negatively influence other competitive priorities (see Table 4).

\section{-Take in Table 4-}

One of the key issues why improvements of these three competitive priorities lead to tradeoffs is because process stability is endangered. Flexible volume changes, high frequency of new product introduction and fast deliveries require changes of the scheduled production procedures, thus encompassing the risk to generate process variances. The analysis shows that if the companies aim to improve one of these three priorities, the achievement of other priorities, namely "low cost", "product design and quality", "conformance quality" and "dependable delivery" is at risk. Based on this, we see the existence of two groups of competitive priorities. Those influencing others ("volume flexibility", "frequency of new product introduction" and "fast delivery") and those only being influenced ("low cost", "product design and quality", "conformance quality" and "dependable delivery"). Improvements of the latter do not negatively influence other priorities. The case studies show that improvements of the first group of competitive priorities negatively affected process stability and transparency, which holds not true for the second group. Therefore, the influence of a competitive priority on process stability and transparency is basis for whether the improvement of this competitive priority leads to tradeoffs or not.

We summarize that companies can compete on multiple competitive priorities simultaneously but that it is crucial to analyse which priorities to combine. Further, if the improvement of a priority leads to process variances, the implementation of supporting actions needs to be considered in order to reduce the resulting tradeoffs. 


\subsection{RQ2: Do action programmes positively influence the simultaneous} implementation of multiple competitive priorities?

The case analysis shows that the implementation of action programmes can reduce tradeoffs. One of the key programmes is JIT. Its implementation supported the reduction of the tradeoffs from "volume flexibility", "frequency of new product introduction", and "fast delivery". One of the main aspects was that the implementation of JIT improved the process transparency and the employee's knowledge about the processes. These changes served as foundation for the implementation of other programmes and initiatives. The programme supported the companies' aim to compete on multiple competitive priorities as it reduces tradeoffs and through the changes, positively influences the improvement of all competitive priorities. Figure 6 shows in which companies (number in brackets) the implementation of JIT reduced the tradeoffs.

Another important programme is continuous improvement. Its implementation has supported the process oriented thinking and with this was a driver for improving process transparency. Process transparency, again, is needed to improve all competitive priorities. In addition, within Cable Inc. and Printer Board Ltd., the programme supported the reduction of "frequency of new product introduction" and "fast delivery" tradeoff.

To reduce the tradeoff resulting from improving the "frequency of new product introduction", Cable Ltd. implemented the programme "project management". The programme influenced the quality of the project management (see Figure 2) through its release of daily duties. With this, high emphasis on the goals of the project was achieved. This programme is designed to combine the goals "frequency of new product introduction", "low cost", “dependable delivery", "fast delivery" and "wide product range". The same tradeoffs have been addressed by Pipe Systems, Printer Board Ltd. 
and Tool Ltd. through the implementation of the programme "integration of product development and production", which also led to higher transparency and a higher process orientation.

However, the bundles of programmes are accompanied by structural initiatives, such as inventory, additional production lines and automation levels. Therefore, we summarize that action programmes influence multiple competitive priorities but are supported by structural/infrastructural initiatives. Figure 6 summarises our findings.

- Take in Figure 6 -

\subsection{RQ3: Which contextual factors influence the relationships between competitive priorities, managerial actions and performance?}

The case study data show differences concerning the measures of how to reduce tradeoffs. The following paragraph discusses possible contextual factors that may be relevant in determining effective measures. Figure 6 exemplifies that the implementation of programmes and other initiatives have different effects on the company's aim to compete on multiple competitive priorities simultaneously.

The first difference stems from the tradeoff "fast delivery" versus "low costs", "product design and quality", "conformance quality" and "dependable delivery". Despite the implemented action programs and initiatives to reduce these tradeoffs, Cable Ltd. and Printer Board Ltd. still face negative effects, while Tool Ltd. reduces the negative effect of "fast delivery" on "product design and quality", "conformance quality" and "dependable delivery" with a large inventory. The "fast delivery" and "low cost" tradeoff still exist as inventory is a cost-intensive solution. Pipe System's case data reveal that its distribution network reduces the effect of fast delivery because the stock of the sales representative acts as a buffer. Therefore, the contextual factors 
leading to differences are inventory management respectively the differences between made-to-order (MTO) and made-to-stock products (MTS).

The analyses of the programmes reveal that the potential to improve competitive priorities is company-specific (see Figure 6). For example, Tool Ltd. and Printer Board Ltd. use JIT to overcome the tradeoffs resulting from the factor "frequency of new product introduction". However, the same is not true for Cable Ltd. and Pipe Systems. When comparing the four case studies, we find differences in their respective product portfolios. It appears that implementing JIT helps companies with a broad product portfolio, as they need to excel in producing the whole portfolio and changes are even more difficult to cope with. Therefore, as JIT leads to a higher process transparency, this programme seems to be especially important for companies covering a broad product portfolio.

Another difference concerns the programme "integration of product development and production" and its potential to reduce the tradeoff resulting from “volume flexibility". Tool Ltd., Printer Board Ltd. and Pipe Systems have implemented the programme, but in comparison with the other two companies, Pipe Systems does not address the factor "volume flexibility" with this programme because of the automation level. The higher the automation level, the lower the influence of the employees on the processes. To fulfil the flexibility requirements, Tool Ltd. and Printer Board Ltd. need skilled employees who can easily implement the changing requirements. However, at Pipe Systems the high automation level ensures that flexibility is not similarly influenced by the employees.

Finally, the potential of the continuous improvement programme to reduce the "frequency of new product introduction" tradeoffs reveal another difference. Printer Board Ltd. and Cable Ltd. show that, based on process improvements, free capacity can 
be generated. Free capacity, in turn, is needed to implement new products. Although free capacity often generates new product introduction, another situation exists at Pipe Systems. The new product introduction is managed top down, and the influence of manufacturing employees is low. Therefore, we suggest that the continuous improvement programme supports the factor "frequency of new product introduction" if the company's decision line is not merely top down but also influenced by manufacturing.

The causalities which resulted from the implementation of action programmes and other initiatives differ within the analysed companies. Therefore, there is a need to consider the contextual factors which may be responsible for the encountered differences. Summarizing, differences occurred due to differences in MTS and MTO philosophy, the size of the product portfolio, the automation level and the leadership style.

\subsection{RQ4: How does a company orchestrate contextual factors, competitive priorities and managerial actions to avoid tradeoffs that negatively influence the multidimensional performance indicators?}

The four analysed plants compete simultaneously on multiple competitive priorities. Table 2 shows that the four consider themselves more successful than their competitors in at least four out of nine performance factors, even though they have to fulfil multiple competitive priorities simultaneously.

In order to understand the differences in the performance judgments, we contrast the competitive priorities the companies want to achieve with the tradeoffs encountered and the initiatives implemented. Although all four companies consider the factor "dependable delivery" as strategically important, only one company, Pipe Systems, achieves a better result than the relevant competitors. This result may be due to 
tradeoffs, as "dependable delivery" is negatively influenced by "volume flexibility" and "frequency of new product introduction". The priority "dependable delivery" has been judged as more important to compete on than "volume flexibility" and "frequency of new product introduction". The company improves the latter two priorities only as long as "dependable delivery" is not negatively influenced. Further, Pipe System has a high automation level. As presented above, this helps Pipe System to reduce the tradeoff from "volume flexibility" and "frequency of new product introduction". In contrast, Cable Ltd. and Printer Board Ltd. put a stronger or equal focus on achieving "volume flexibility" or "frequency of new product introduction" as to excel on "dependable delivery". Therefore, they have to cope with the effect that the priority "dependable delivery" is only partly achieved. Similar to Pipe Systems, Tool Ltd. puts a stronger focus on achieving "dependable delivery" than "volume flexibility" and "frequency of new product introduction" but does not achieve a better result in "dependable delivery" than the competitors. The initiative to have spare capacity which should allow to improve "volume flexibility" and "frequency of new product introduction" seems less effective than Pipe Systems investments in the automation level. Summarizing, it appears that the combination of "dependable delivery" with "volume flexibility" and "frequency of new product introduction" is difficult and needs either a transparent order of importance or clearly defined initiatives.

The priority "product design and quality" reveals a similar situation. This priority is considered important by all four companies and is also influenced by the factors "volume flexibility" and "frequency of new product introduction". Although the initiatives of Cable Ltd. and Pipe Systems seem to have minimised the tradeoff more successfully than their competitors, the same was not true at Printer Board Ltd. or Tool Ltd. 
Although Table 2 shows that companies can be successful in multiple performance dimensions, it also shows that some factors (e.g., "product design and quality" and "dependable delivery") are more difficult to combine than others ("wide product range" and "innovative products"). These factors are not influenced by other factors nor do they influence other factors. Therefore, these factors are easier to include in the manufacturing strategy.

Overall, the results show that in order to compete successfully on multiple competitive priorities, companies need to take into account the highly complex interdependencies between contextual factors, competitive priorities, action programs and structural/infrastructural changes. Depending on the chosen strategy and the contextual factors, each company implemented a different combination of action programs and structural/infrastructural initiatives. Therefore, rather than to recognize a best-in-class method, it is the fit between the dimensions that supports the companies to achieve a good market position.

\section{Summary and Conclusion}

The need to compete on multiple competitive priorities is widely recognised. Many researchers have analysed the sequence of multiple competitive priorities (Schroeder and Pesch 1994). We have put our focus on analysing how priorities interrelate and which means can solve possible tradeoffs. The case studies reveal the complex interactions between competitive priorities, tradeoffs, action programmes, contextual factors and performance. Concerted actions are needed to reduce tradeoffs and to achieve better results than competitors. Therefore, the analysis yielded ideas on how to successfully compete on multiple competitive priorities.

Competing on multiple competitive priorities seems to be dependent on the combination of priorities. Some priorities seem to be more likely to negatively influence 
other priorities ("volume flexibility", "frequency of new product introduction" and "fast delivery"). Such tradeoffs must be minimised. We identify two methods for doing so. First, companies can make structural changes, such as installing two additional production lines or storing end products, even though the latter is a contradiction to today's attempts in implementing efficiency initiatives such as lean. Second, companies can implement action programmes. In addition, we showed that three different types of competitive priorities consist. The first type generates tradeoffs. The second type is influenced by other competitive priorities. Finally, the third type holds isolated factors which can easily be combined.

The study shows that companies can consciously choose which tradeoffs they want to address and decrease (Clark 1996, Da Silveira 2005), but the companies have to control the indirect relationships between the different action programmes to avoid negative influences of the chosen action on other tradeoffs. Therefore, tradeoffs are not exogenous. In alignment with Schroeder et al. (2011), the study shows the importance of contextual factors. We add to the findings of Olhager and Prajogo (2012), who show that MTO and MTS plants have a different action programme-performance relationship. Hence, we agree that MTO/MTS should be included in further research studies to detect differences of other factors. In addition, the different leadership styles, the product portfolio offered and the automation level should be considered to understand differences between the analysed dimensions.

Implementing action programmes influences multidimensional performance measures. Although JIT is an action programme that by itself influences multiple performance dimensions, the main effects are mostly achieved through bundles of practises. In accordance with Shah and Ward (2003) and Cua et al. (2001), we confirm that bundles of practises must be analysed rather than single practises. In other words, to 
be successful in multiple performance dimensions, companies need bundles of practises. Furthermore, single action programmes, such as JIT, are the foundation for other initiatives such as hiring temporary employees. This highlights the importance of considering the changes the implementation of action programs leads to and which additional programmes or initiatives (changes in structure/infrastructure) are needed to achieve the set goals. This leads to a further result. In order to compete successfully on multiple competitive priorities, companies must not only orchestrate action programmes but also changes in structure and infrastructure. Therefore, there is a need to explicitly combine action programmes and infrastructural/structural decisions in manufacturing strategy content and an isolated focus on one of the two dimensions does not fully cover the interdependencies.

The in-depth analysis of four Swiss manufacturing plants provided insight into how multiple competitive priorities can be addressed simultaneously, and we demonstrated that contextual factors influence the existence of tradeoffs and the impact of action programmes. These preliminary results must be tested on a larger data set to determine if any patterns can be identified among contextual factors and tradeoffs. In addition, we must search for any patterns among the combinations of contextual factors and the relationships between actions and strategic goals. Finally, we must test if differences in geographical terms exist.

Another limitation concerns the lack of quantitative key performance indicators, though each of the interview partners has worked more than ten years in the analysed companies and has excellent market knowledge. To overcome possible employee bias, we explained each dimension, and both interviewees had to come to the same conclusion. Future studies should consider including objective data to measure these changes. 


\section{References}

Anand, G. and Ward, P. T., 2004. Fit, Flexibility and Performance in Manufacturing: Coping with Dynamic Environments. Production \& Operations Management, 13(4), 369-385.

Boyer, K. K. and Lewis, M. W., 2002. Competitive Priorities: Investigating The Need For Trade-Offs In Operations Strategy. Production \& Operations Management, 11(1), 9-20.

Bozarth, C. and Edwards, S., 1997. The impact of market requirements focus and manufacturing characteristics focus on plant performance. Journal of Operations Management, 15(3), 161-180.

Brown, S., Squire, B. and Lewis, M., 2010. The impact of inclusive and fragmented operations strategy processes on operational performance. International Journal of Production Research, 48(14), 4179-4198.

Chen, I. J. and Paulraj, A., 2004. Towards a theory of supply chain management: the constructs and measurements. Journal of Operations Management, 22(2), 119150.

Christiansen, T., et al., 2003. A mapping of competitive priorities, manufacturing practices, and operational performance in groups of Danish manufacturing companies. International Journal of Operations \& Production Management, 23(10), 1163-1183.

Clark, K. B., 1996. Competing Through Manufacturing and the New Manufacturing Paradigm: Is Manufacturing Strategy Passé? Production and Operations Management, 5(1), 42-58.

Corbett, C. and Van Wassenhove, L., 1993. Trade-offs? What trade-offs? Competence and competitiveness in manufacturing strategy. California Management Review, 35(4), 107-122.

Corbett, L. M. and Claridge, G. S., 2002. Key manufacturing capability elements and business performance. International Journal of Production Research, 40(1), 109-131.

Cua, K. O., Mc Kone, K. E. and Schroeder, R. G., 2001. Relationships between implementation of TQM, JIT, and TPM and manufacturing performance. Journal of Operations Management, 19(6), 675-694.

Da Silveira, G. J. C., 2005. Improving trade-offs in manufacturing: Method and illustration. International Journal of Production Economics, 95, 27-38.

Da Silveira, G. J. C. and Slack, N., 2001. Exploring the trade-off concept. International Journal of Operations \& Production Management, 21(7), 949-964.

Dangayach, G. S. and Deshmukh, S. G., 2001. Manufacturing strategy: Literature review and some issues. International Journal of Operations \& Production Management, 21(7), 884-933.

Davis, J. P., Eisenhardt, K. M. and Bingham, C. B., 2007. Developing theory through simulation methods. Adacemy of Management Review, 32(2), 480-499.

Dean, J. W. J. and Snell, S. A., 1996. The Strategic Use of Integrated Manufacturing: An Empirical Examination. Strategic Management Journal, 17(6), 459-480.

Deflorin, P. and Scherrer-Rathje, M., 2011. Challenges in the transformation to lean production from different manufacturing-process choices: a path-dependent perspective. International Journal of Production Research, 1-18.

Dilman, D. A., 1978. Mail and Telephone Surveys. New York, NY: Wiley.

Eisenhardt, K. M., 1989. Building Theories from Case Study Research. Academy of Management Review, 14(4), 532-550. 
Eisenhardt, K. M. and Zbarac, M. J., 1992. Strategic decision making. Strategic Management Journal, 13(Special Issue), 17-37.

Ferdows, K. and De Meyer, A., 1990. Lasting improvements in manufacturing performance: In search of a new theory. Journal of Operations Management, 9(2), 168-184.

Ferdows, K., et al., 1986. Evolving Global Manufacturing Strategies: Projections into the 1990s. International Journal of Operations \& Production Management, 6(4), 6-16.

Ferdows, K. and Thurnheer, F., 2011. Building factory fitness. International Journal of Operations and Production Management, 31(9), 916 - 934.

Flynn, B. B. and Flynn, E. J., 2004. An exploratory study of the nature of cumulative capabilities. Journal of Operations Management, 22(5), 439-457.

Flynn, B. B., Huo, B. and Zhao, X., 2010. The Impact of Supply Chain Integration on Performance: A Contingency and Configuration Approach. Journal of Operations Management, 28(1), 58-71.

Frohlich, M. T. and Dixon, J. R., 2001. A taxonomy of manufacturing strategies revisited. Journal of Operations Management, 19(5), 541-558.

Gerwin, D., 1993. Manufacturing Flexibility: A Strategic Perspective. Management Science, 39(4), 395-410.

Groessler, A., 2007. A dynamic view on strategic resources and capabilities applied to an example from the manufacturing strategy literature. Journal of Manufacturing Technology Management, 18(3), 250-266.

Handfield, R. B. and Melynk, S. A., 1998. The Scientific Theory - Building Process: A Primer using the Case of TQM. Journal of Operations Management, 16(4), 322339.

Hayes, R. H. and Pisano, G. P., 1996. Manufacturing Strategy: At the Intersection of Two Paradigms. Production and Operations Management, 5(1), 25-41.

Hayes, R. H., et al., 2005. Operations, Strategy, and Technology. Pursuing the Competitive Edge. Wiley, Hoboken, NJ.

He, Z.-L. and Wong, P.-K., 2004. Exploration vs. Exploitation: An Empirical Test of the Ambidexterity Hypothesis. Organization Science, 15(4), 481-494.

Hill, T., 2000. Manufacturing strategy: Text and cases. New York: Palgrave.

Kathuria, R., 2000. Competitive priorities and managerial performance: a taxonomy of small manufacturers. Journal of Operations Management, 18(6), 627-641.

Ketokivi, M. and Schroeder, R., 2004a. Manufacturing practices, strategic fit and performance A routine-based view. International Journal of Operations \& Production Management, 24(2), 171-191.

Ketokivi, M. and Schroeder, R., 2004b. Strategic, structural contingency and institutional explanations in the adoption of innovative manufacturing practices. Journal of Operations Management, 22, 63-89.

Kim, J. S. and Arnold, P., 1996. Operationalizing manufacturing strategy. An exploratory study of constructs and linkage. International Journal of Operations \& Production Management, 16(12), 45-73.

Laugen, B. T., et al., 2005. Best manufacturing practices: What do the best-performing companies do? International Journal of Operations \& Production Management, 25(2), 131-150.

Mapes, J., New, C. and Szwejczewski, M., 1997. Performance trade-offs in manufacturing plants. International Journal of Operations \& Production Management, 17(9/10), 1020-1033. 
Miles, M. B. and Huberman, A. M., 1994. Qualitative data analysis. Thousand Oaks, CA: Sage.

Mills, J., Platts, K. and Gregory, M., 1995. A framework for the design of manufacturing strategy processes. A contingency approach. International Journal of Operations \& Production Management, 15(4), 17-49.

Miltenburg, J., 2009. Setting manufacturing strategy for a company's international manufacturing network. International Journal of Production Research, 47(22), 6179-6203.

Narasimhan, R., Swink, M. and Kim, S. W., 2005. An exploratory study of manufacturing practice and performance interrelationships. Implications for capability progression. International Journal of Operations \& Production Management, 25(10), pp. 1013-1033.

Noble, M. A., 1997. Manufacturing competitive priorities and productivity: An empirical study. International Journal of Operations \& Production Management, 17(1/2), 85-99.

Olhager, J. and Prajogo, D. I., 2012. The impact of manufacturing and supply chain improvement initiatives: A survey comparing make-to-order and make-to-stock firms. Omega, 40(2), 159-165.

Oppenheim, A. N., 1992. Questionnaire Design, Interviewing and Attitude Measurement. London: Printers Publication.

Ritzman, L. P. and Safizadeh, M. H., 1999. Linking process choice with plant level decisions about capital and human resources. Production and Operations Management.

Roth, K. and Morrison, A. J., 1992. Implementing global strategy: characteristics of global subsidiary mandates. Journal of International Business Studies, 23(4), 715-735.

Schroeder, R. G. and Pesch, M. J., 1994. Focusing the factory: Eight lessons. Business Horizons, 37(5), 76-81.

Schroeder, R. G., Shah, R. and Xiaosong Peng, D., 2011. The cumulative capability 'sand cone' model revisited: a new perspective for manufacturing strategy. International Journal of Production Research, 49(16), 4879-4901.

Shah, R. and Ward, P., 2007. Defining and developing measures of lean production. Journal of Operations Management, 25, 785-805.

Shah, R. and Ward, P. T., 2003. Lean manufacturing: context, practice bundles, and performance. Journal of Operations Management, 21(2), 129-149.

Skinner, W., 1969. Manufacturing - missing link in corporate strategy. Harvard Business Review, 47(3), 136-145.

Skinner, W., 1974. The focused factory. Harvard Business Review, 52(3), 113-121.

Spring, M. and Boaden, R., 1997. “One more time: how do you win orders?”: a critical reappraisal of the Hill manufacturing strategy framework. International Journal of Operations \& Production Management, 17(8), 757-779.

Sterman, J. D., 2000. Business Dynamics: Systems Thinking and Modeling for a Complex World. Versailles: Jeffrey J. Shelstafd.

Stuart, I., et al., 2002. Effective case research in operations management: a process perspective. Journal of Operations Management, 20(5), 419-433.

Venkatraman, N., 1989. The Concept of Fit in Strategy Research: Toward Verbal and Statistical Correspondence. Academy of Management Review, 14(1), 423-444.

Vickery, S. K., Droge, C. and Markland, R. E., 1997. Dimensions of manufacturing strength in the furniture industry. Journal of Operations Management, 15(4), 317-330. 
Voss, C., Tsrikriktsis, N. and Frohlich, M., 2002. Case research in Operations Management. Journal of Operations and Production Management, 22(2).

Ward, P. T., Leong, G. K. and Boyer, K. K., 1994. Manufacturing proactiveness and performance. Decision Sciences, 27(3), 123-138.

Ward, P. T., et al., 1998. Competitive priorities in operations management. Decision Sciences, 27(3), 1035-1046.

Wheelwright, S. C. and Hayes, R. H., 1985. Competing through manufacturing. Harvard Business Review, 63(1), 99-109.

Yin, R. K., 1994. Case Study Research: Design and Methods. 2nd edition ed.: Sage Publications. 


\section{Appendix}

Semi-structured interview guideline for interviews with CEO and manufacturing manager.

Competitive Priorities:

- You have judged each competitive priority according to the importance. Do you strive to compete on each priority labelled as important?

- Please describe the competitive priorities in your own words.

- Is the performance level of the competitive priorities higher or lower than the one of your relevant competitors? Please describe why.

Action Programs:

- Which action programs do you consider as especially helpful in order to achieve your competitive priorities? Why?

- How did you implement the action programs?

- What has changed after the implementation?

- Have the action programs been accompanied with structural and/or infrastructural changes?

- Describe which competitive priorities were influenced through the changes and how.

- Did the improvement of one priority lead to a negative effect of another priority?

- What did you do to reduce the tradeoffs? 
Figure 1: Research framework

Striving for fit $R Q 4$

\begin{tabular}{|c|c|c|}
\hline $\begin{array}{l}\text { Multi competitive priorities } \\
\text { (strategic goals) } \\
\text { Cost } \overbrace{\substack{\text { Tradeoffs } \\
R Q 1} \text { Dependability }}^{\text {Quality }}\end{array}$ & RQ2 & Cost $\overbrace{\text { Dependability }}^{\text {Multidimensional }}$ Performance \\
\hline Innovation Flexibility & \multirow{2}{*}{$\begin{array}{l}\text { Managerial actions to } \\
\text { implement competitive } \\
\text { priorities }\end{array}$} & \multirow[t]{4}{*}{ Innovation Flexibility } \\
\hline & & \\
\hline & $\begin{array}{l}\text { Action } \\
\text { Programmes }\end{array}$ & \\
\hline Context RQ3 & $\begin{array}{l}\text { Infrastructural and } \\
\text { structural initiatives }\end{array}$ & \\
\hline
\end{tabular}


2

Table 1: Overview of contextual factors

\begin{tabular}{|l|l|l|l|l|}
\hline & Cable Ltd. & Pipe Systems & Printer Board Ltd. & Tool Ltd. \\
\hline Company size & $\begin{array}{l}1000 \text { employees, } \\
5 \text { plants }\end{array}$ & $\begin{array}{l}1500 \text { employees, } \\
5 \text { plants }\end{array}$ & $\begin{array}{l}2200 \text { employees, } 7 \\
\text { plants }\end{array}$ & $\begin{array}{l}450 \text { employees, } \\
\text { plants }\end{array}$ \\
\hline $\begin{array}{l}\text { Geographic } \\
\text { focus }\end{array}$ & International & International & International & International \\
\hline Network & Global network & Global network & Global network & Small network \\
\hline $\begin{array}{l}\text { Distribution } \\
\text { network }\end{array}$ & No stock & $\begin{array}{l}\text { Stock owned } \\
\text { by sales } \\
\text { representatives }\end{array}$ & No stock & $\begin{array}{l}\text { Stock owned by } \\
\text { Tool Ltd. }\end{array}$ \\
\hline $\begin{array}{l}\text { Dependence on } \\
\text { third party }\end{array}$ & $\begin{array}{l}\text { Low (strong } \\
\text { internal network) }\end{array}$ & $\begin{array}{l}\text { Low (strong } \\
\text { internal network) }\end{array}$ & $\begin{array}{l}\text { Low (strong } \\
\text { internal network) }\end{array}$ & $\begin{array}{l}\text { High (collaboration } \\
\text { with suppliers } \\
\text { important) }\end{array}$ \\
\hline $\begin{array}{l}\text { Product } \\
\text { characteristics }\end{array}$ & Modularized & Standardized & $\begin{array}{l}\text { Individualized } \\
\text { products }\end{array}$ & Standardized \\
\hline Product portfolio & Low product mix & Low product mix & High product mix & High product mix \\
\hline $\begin{array}{l}\text { Plant layout } \\
\text { (automation } \\
\text { level) }\end{array}$ & Low automation & $\begin{array}{l}\text { High automation } \\
\text { level }\end{array}$ & $\begin{array}{l}\text { Low automation } \\
\text { level }\end{array}$ & $\begin{array}{l}\text { Medium } \\
\text { automation level }\end{array}$ \\
\hline $\begin{array}{l}\text { Production } \\
\text { process }\end{array}$ & Batch & Continuous flow & Batch & Batch \\
\hline
\end{tabular}


Table 2: Competitive priorities of the four companies and performance

\begin{tabular}{|c|c|c|c|c|c|c|c|c|c|c|c|c|c|}
\hline & & \multicolumn{3}{|c|}{ Cable Ltd. } & \multicolumn{3}{|c|}{ Pipe Systems } & \multicolumn{3}{|c|}{$\begin{array}{l}\text { Printer Board } \\
\text { Ltd. }\end{array}$} & \multicolumn{3}{|c|}{ Tool Ltd. } \\
\hline \multicolumn{2}{|c|}{ Competitive priorities } & A & B & C & A & B & C & A & B & C & A & B & C \\
\hline Price & Low price & 3 & - & No & 4 & - & No & 4 & $x$ & No & 3 & - & No \\
\hline \multirow[t]{2}{*}{ Quality } & Conformance quality & 4 & $x$ & Yes & 5 & $x$ & Yes & 4 & $x$ & Yes & 4 & $x$ & No \\
\hline & $\begin{array}{l}\text { Product design and } \\
\text { quality }\end{array}$ & 4 & $x$ & Yes & 5 & $\mathrm{X}$ & Yes & 4 & $x$ & No & 4 & $x$ & No \\
\hline \multirow[t]{2}{*}{ Delivery } & Fast delivery & 4 & $x$ & Yes & 3 & $x$ & Yes & 5 & $x$ & Yes & 5 & $x$ & Yes \\
\hline & Dependable delivery & 4 & $x$ & No & 5 & $x$ & Yes & 5 & $x$ & No & 5 & $x$ & No \\
\hline \multirow[t]{2}{*}{ Flexibility } & Wide product range & 4 & $x$ & Yes & 4 & $x$ & Yes & 3 & $x$ & Yes & 4 & $x$ & Yes \\
\hline & Volume flexibility & 4 & $\mathrm{x}$ & Yes & 3 & $\mathrm{X}$ & Yes & 5 & $x$ & No & 3 & $x$ & Yes \\
\hline \multirow[t]{2}{*}{ Innovation } & Innovative product & 4 & $x$ & Yes & 5 & $x$ & Yes & 2 & - & No & 4 & $x$ & Yes \\
\hline & $\begin{array}{l}\text { Frequency of new } \\
\text { product introduction }\end{array}$ & 3 & $x$ & Yes & 4 & $x$ & Yes & 4 & $x$ & Yes & 4 & $x$ & Yes \\
\hline \multicolumn{2}{|c|}{ Sum of the competitive priorities } & & 8 & 7 & & 8 & 8 & & 8 & 4 & & 8 & 5 \\
\hline \multicolumn{2}{|c|}{$\begin{array}{l}\text { Industry analysis: based on sales, } \\
\text { company ranks... }\end{array}$} & \multicolumn{3}{|c|}{$\begin{array}{l}\text { First (market } \\
\text { leader) }\end{array}$} & \multicolumn{3}{|c|}{ First (market leader) } & \multicolumn{3}{|c|}{ Fourth } & \multicolumn{3}{|c|}{ Third } \\
\hline
\end{tabular}

Legend:

$A=$ Importance from 1 (low) to 5 (high)

$\mathrm{B}=$ Company aims at $(\mathrm{X}=$ yes $/-=$ no $)$

$\mathrm{C}=$ Better than competitor 


\begin{tabular}{|c|c|c|}
\hline \multirow[t]{3}{*}{ Cable Inc. } & Action Programmes & $\begin{array}{l}\text { - JIT } \\
\text { - } \text { Continuous improvement (Cl) } \\
\text { - Project Management (PM) }\end{array}$ \\
\hline & Other Initiatives & $\begin{array}{l}\text { - Temporary employees } \\
\text { - Different production lines }\end{array}$ \\
\hline & Lessons learned & $\begin{array}{l}\text { - Improvements of "volume flexibility", "frequency of new product introduction" and "fast } \\
\text { delivery" negatively influences other competitive priorities. } \\
\text { - The combination of JIT, temporary employees and different production lines (i.e. flex-shop, } \\
\text { express-shop) enabled the reduction of the flexibility tradeoff. } \\
\text { - The reduction of the tradeoff resulting from a higher frequency of new product introduction } \\
\text { was achieved through the implementation of } \mathrm{Cl} \text { and PM. } \\
\text { - The combined implementation of JIT, Cl, PM and different production lines supported the } \\
\text { reduction of the fast delivery tradeoff. }\end{array}$ \\
\hline \multirow[t]{3}{*}{$\begin{array}{l}\text { Pipe } \\
\text { Systems }\end{array}$} & Action Programmes & $\begin{array}{ll}\text { - JIT } \\
\text { - Integration of product development and production }\end{array}$ \\
\hline & Other Initiatives & - Process automation \\
\hline & Lessons learned & $\begin{array}{l}\text { - Improvements of "volume flexibility" and "frequency of new product introduction" negatively } \\
\text { influences other competitive priorities. } \\
\text { - The implementation of JIT and improvements in process automation enabled the reduction of } \\
\text { the flexibility tradeoff. } \\
\text { - In addition to investments in process automation, the integration of product development and } \\
\text { production activities supported the reduction of the frequency of new product introduction } \\
\text { tradeoff. } \\
\text { - The fast delivery tradeoff is not present at Pipe Systems because the stock of sales } \\
\text { representative acts as a buffer. }\end{array}$ \\
\hline \multirow[t]{3}{*}{$\begin{array}{l}\text { Printer } \\
\text { Board Ltd. }\end{array}$} & Action Programmes & $\begin{array}{l}\text { - JIT } \\
\text { - Continuous improvement (Cl) } \\
\text { - Project Management (PM) } \\
\text { - Integration of product development and production }\end{array}$ \\
\hline & Other Initiatives & - Internal production networks \\
\hline & Lessons learned & $\begin{array}{l}\text { - Improvements of "volume flexibility", "frequency of new product introduction" and "fast } \\
\text { delivery" negatively influences other competitive priorities. } \\
\text { - The implementation of JIT and transferring orders to the internal network helped Printer Board } \\
\text { - Ltd. to reduce the volume flexibility tradeoff. } \\
\text { - The combined implementation of JIT, Cl and the integration of product development and } \\
\text { production supported the reduction of the frequency of new production tradeoff. } \\
\text { - The implementation of JIT, Cl and PM helped to reduce the fast delivery tradeoff. }\end{array}$ \\
\hline \multirow[t]{3}{*}{ Tool Ltd. } & Action Programmes & $\begin{array}{l}\text { - JIT } \\
\text { - Integration of product development and production }\end{array}$ \\
\hline & Other Initiatives & $\begin{array}{l}\text { - Internal production networks } \\
\text { - Spare capacity } \\
\text { - End product storage }\end{array}$ \\
\hline & Lessons learned & $\begin{array}{l}\text { - Improvements of "volume flexibility" and "frequency of new product introduction" negatively } \\
\text { - To be able to fulfil the customers need for faster deliveries, Tool Ltd. invested in an end } \\
\text { - product storage. The remaining tradeoff is "fast delivery" and "low cost". } \\
\text { - The implementation of JIT and the transfer of mature products to a low-cost plant supported } \\
\text { the reduction of the volume flexibility tradeoff. } \\
\text { - JIT, the integration of product development and production and spare capacity allowed Tool } \\
\text { Ltd. to reduce the frequency of new product introduction tradeoff. }\end{array}$ \\
\hline
\end{tabular}


Table 4: Sum of the encountered tradeoffs between competitive priorities

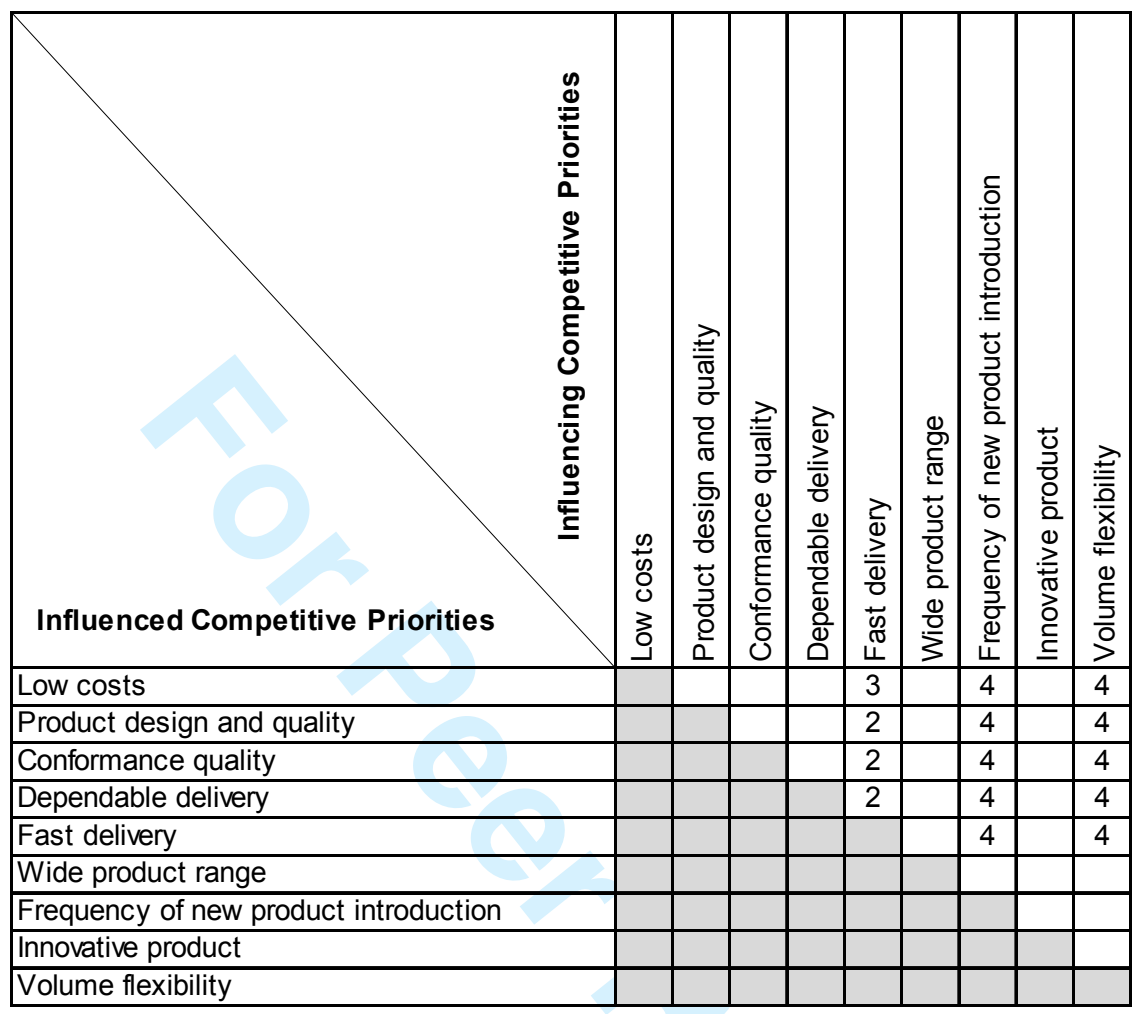


Figure 2: Causal loop diagram of Cable Inc. after the implementation of action programs and other initiatives

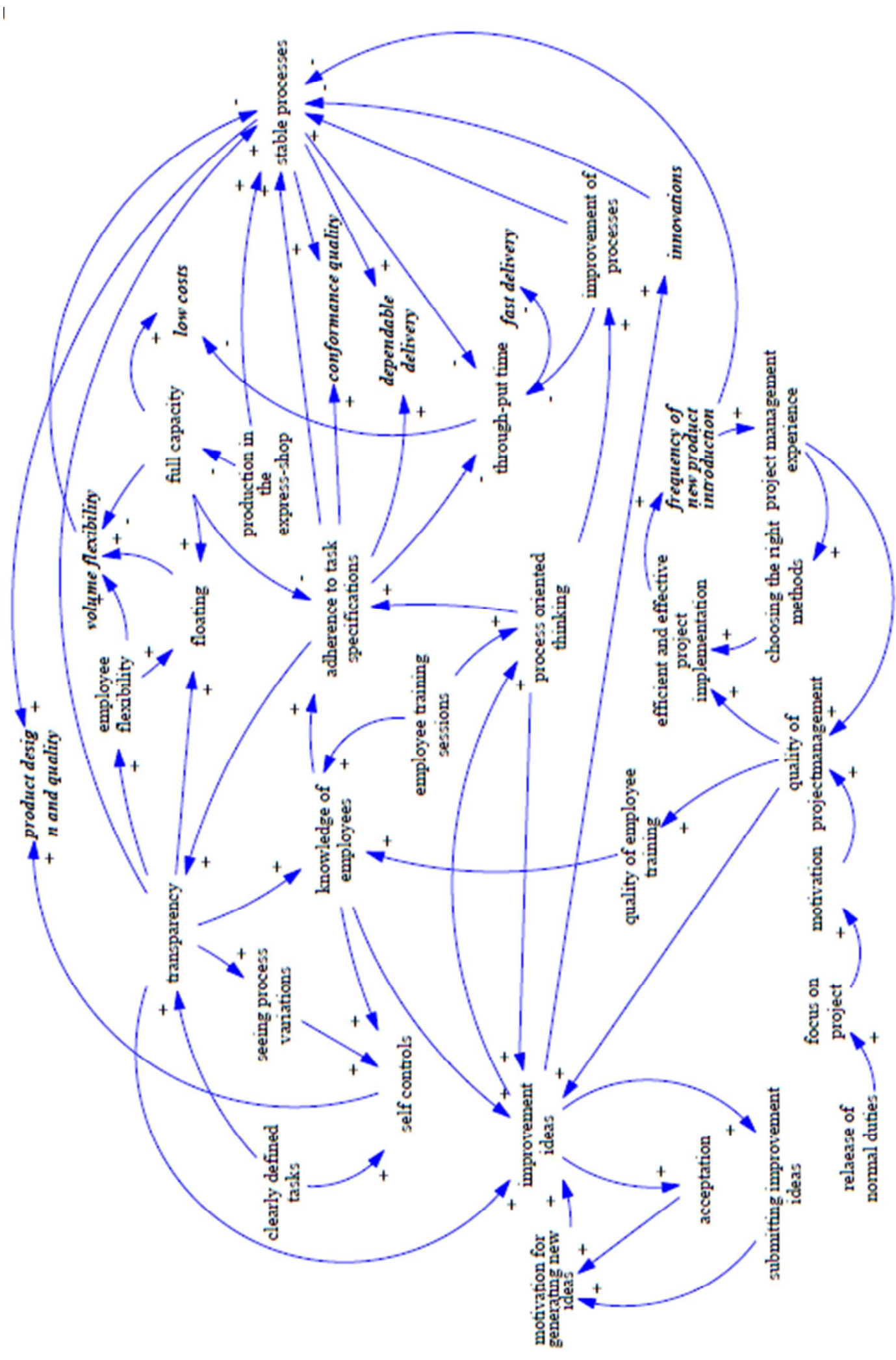

http://mc.manuscriptcentral.com/tprs Email: ijpr@tandf.co.uk 
Figure 3: Causal loop diagram of Pipe Systems after the implementation of action programs and other initiatives

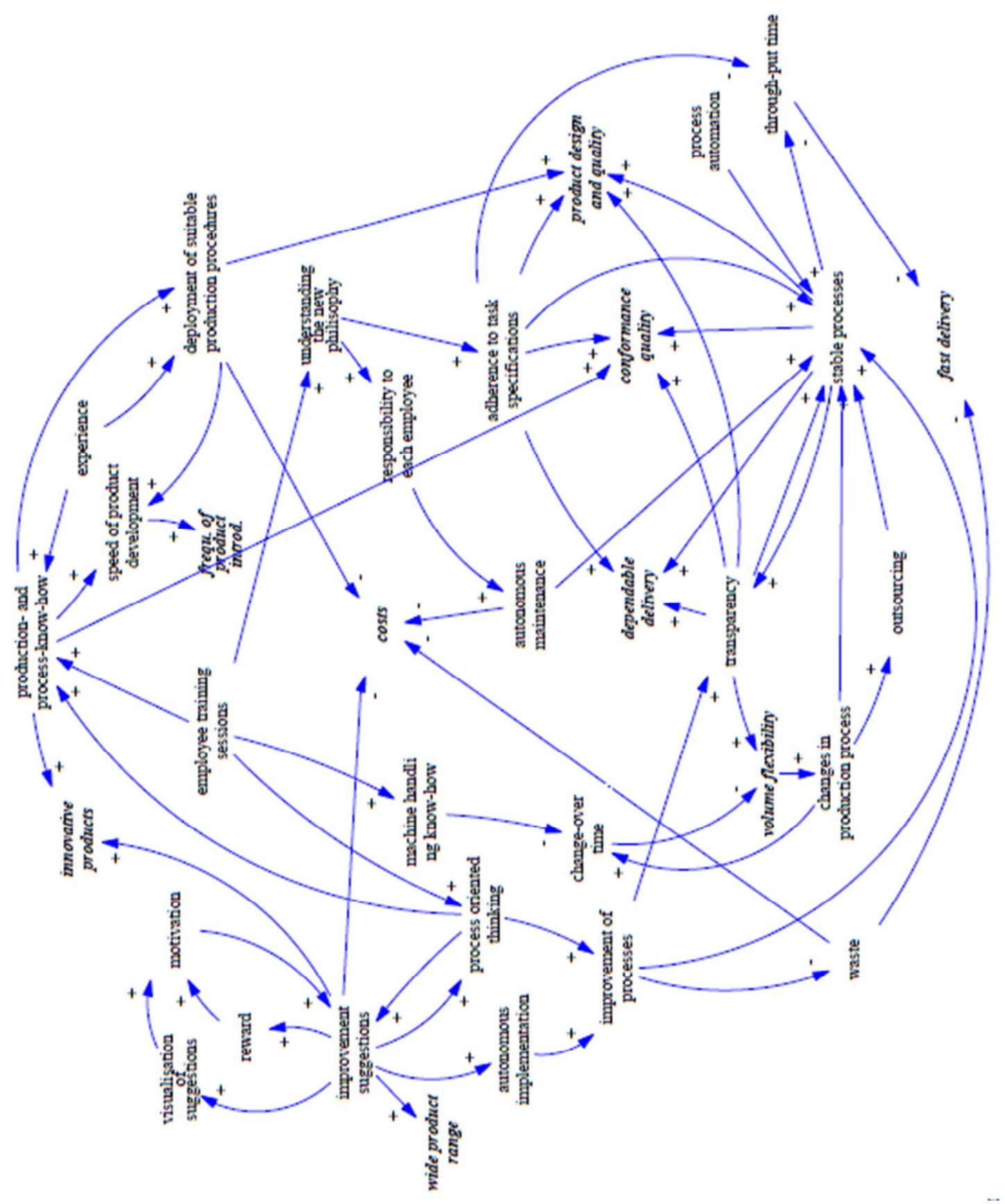

http://mc.manuscriptcentral.com/tprs Email: ijpr@tandf.co.uk 
Figure 4: Causal loop diagram of Printer Board Ltd. after the implementation of action programs and other initiatives

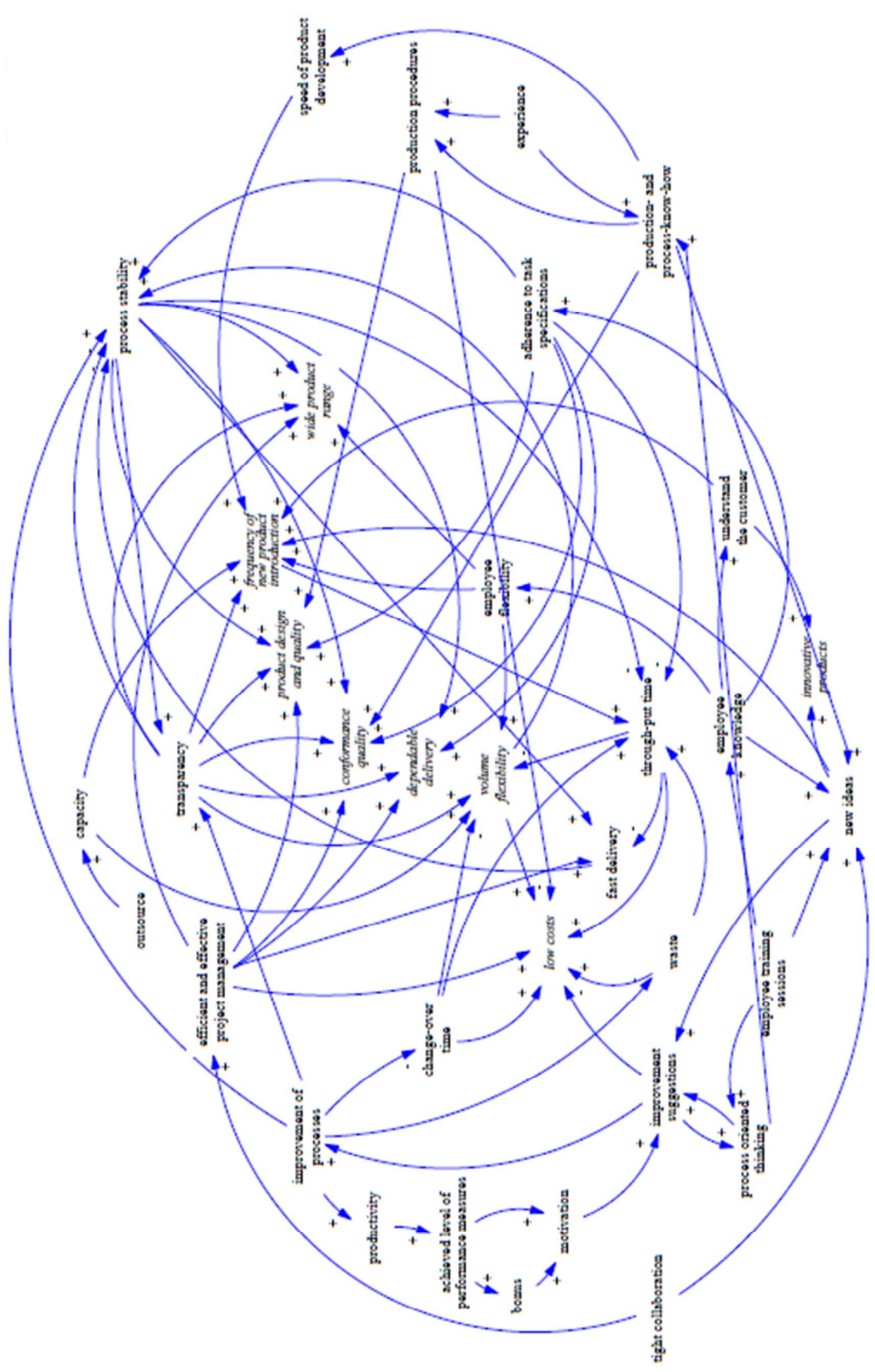

http://mc.manuscriptcentral.com/tprs Email: ijpr@tandf.co.uk 
Figure 5: Causal loop diagram of Tool Ltd. after the implementation of action programs and other initiatives

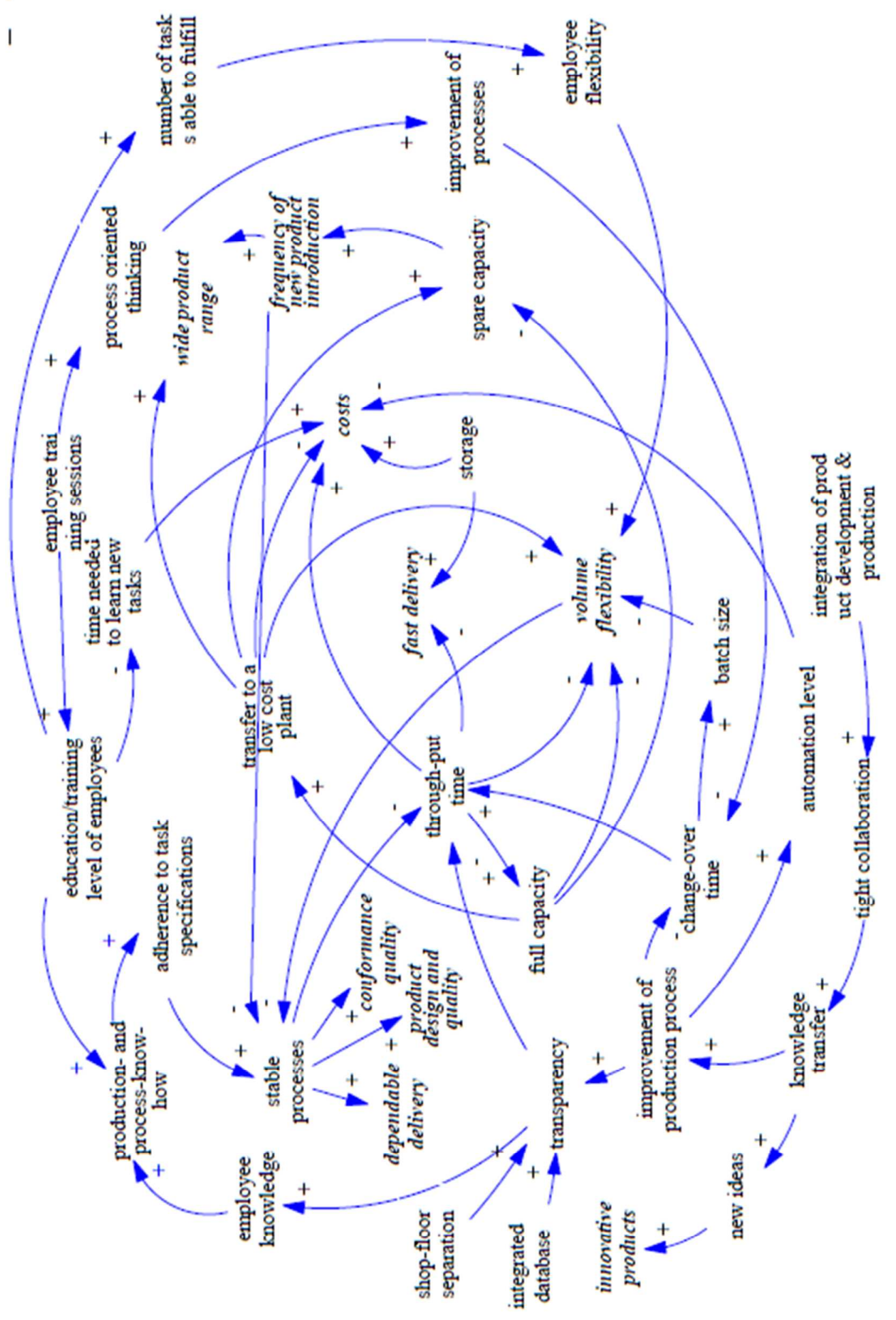

http://mc.manuscriptcentral.com/tprs Email: ijpr@tandf.co.uk 
Figure 6: Tradeoffs and managerial actions
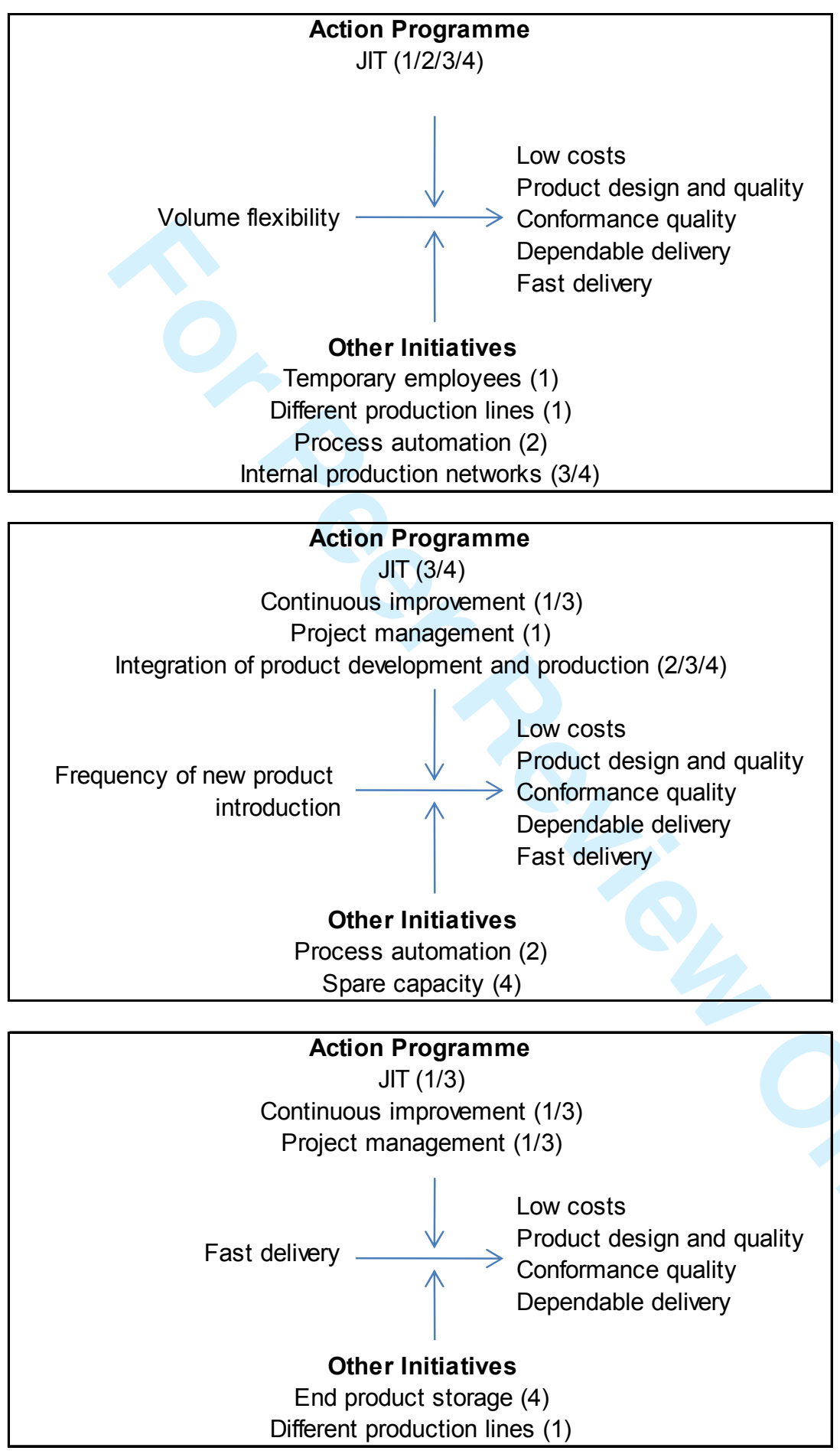

$1=$ Cable Inc.

2= Pipe Systems

$3=$ Printer Boarder Ltd.

$4=$ Tool Ltd. 